\title{
PENGARUH KERAPATAN POHON DAN PEMUPUKAN NITROGEN TERHADAP PERTUMBUHAN DAN PRODUKTIVITAS RUMPUT DI BAWAH TEGAKAN SAMAMA (Anthocephalus macrophyllus (Roxb. Havil.)
}

\author{
Effect of Nitrogen Fertilization and Tree Density on The Growth and Productivity of Grass \\ under Samama (Anthocephalus macrophyllus (Roxb. Havil.) Stand
}

\author{
Sri Handayani ${ }^{1)}$, Irdika Mansur ${ }^{1)}$, Panca Dewi Manohara Karti ${ }^{2)}$
}

(Diterima Januari 2018/ Disetujui Juli 2019)

\begin{abstract}
Samama (Anthocephalus marcophyllus Roxb.Havil) is a tree with a canopy like a large umbrella so that if planted at any distance it will not affect the shape of the stem (Halawane et al. 2011). This type can flourish in tropical forests with an altitude of 50-1000 mdpl. This is including native Indonesian plants that have the potential to be developed in the development of plantation forests and for other purposes, such as reclamation of ex-mining land, reforestation and shade trees (Mansur and Tuheteru 2010). This is because samama can grow on various types of soil, do not have serious pests and diseases (Pratiwi 2003). In accordance with the permit for the implementation of silvopatura activities in production forest areas which are explained in full in the regulations of the Ministery of Environment and Forestry of the Republic of Indonesia No. P.14/Menlhk-11/2015 concerning procedures for granting business licenses for the utilization of silvopastura areas in production forests with the aim of ensuring sustainable forest management by applying the principles of good governance. In the framework of sustainable production forest management to support food sovereignty programs. Provision of sufficient light space, fertilize and selection of tolerant grass species under stands are the key to the success of silvopastura. Based on the results of the study, it was found that the density of trees with 2 tree/plot with light intensity in the morning was $70.48 \%$ and $95.29 \%$ during the day. Addition of nitrogen to grass is not needed if the soil used has good fertility. Pennisetum purpureum Cv. Mott has the best tolerance under the same stand as a source of cut grass (intensive retention) and Stenotaphrum secundatum a coarse, hardly perennial grass in the management of silvopastura extensive.
\end{abstract}

Key words: silvopasture, density of tree, shade, samama

\section{PENDAHULUAN}

Hutan memiliki peranan penting dalam mempengaruhi keberlanjutan lingkungan. Menurut Undang-undang No. 41/1999 hutan mempunyai 3 fungsi yaitu: fungsi konservasi, fungsi lindung, dan fungsi produksi. Hutan tanaman industri adalah hutan tanaman yang dibangun dalam rangka meningkatkan potensi dan kualitas hutan produksi dengan menerapkan silvikultur intensif untuk memenuhi kebutuhan bahan baku industri hasil hutan. Disebutkan dalam Permen Lingkungan Hidup dan Kehutanan RI No. P. 12/2015 optimalisasi pemanfaatan lahan hutan di areal izin usaha hutan tanaman dengan pola tanam kombinasi antara tanaman hutan yang berupa pohon dengan tanaman selain pohon dan/atau hewan untuk meningkatkan produktifitas lahan hutan tanaman dengan tidak mengubah fungsi pokok usaha pemanfaatan hasil hutan kayu (agroforestri).

Silvopastura adalah salah satu kegiatan agroforestri, yang mana di dalamnya terdapat kombinasi secara proporsional dengan usaha peternakan yang meliputi pelepasliaran dan/atau pengandangan ternak. Berdasarkan instruksi Presiden Jokowi yang

\footnotetext{
${ }^{1}$ Departemen Silvikultur, Fakultas Kehutanan IPB

University

${ }^{2}$ Departemen Ilmu Nutrisi dan Teknologi Pakan, Fakultas Peternakan, IPB University

* Penulis korespondensi:

Email: yanimustava89@gmail.com
}

menargetkan swasembeda protein pada tahun 2026, dimana daging sapi sangat penting untuk kehidupan manusia (Lawrie 2003); dan sesuai dengan izin pelaksanaan kegiatan silvopastura pada kawasan hutan produksi yang diatur secara lengkap dalam Peraturan Menteri Lingkungan Hidup dan Kehutanan Republik Indonesia No.P.14/Menlhk-II/2015.

Kegiatan silvopastura belum banyak dilaksanakan di Indonesia, untuk itu perlu diketahui jenis-jenis pohon dan rumput yang dapat diintegrasikan dalam pola silvopastura. Samama (Anthocephalus marcophyllus Roxb.Havil) atau biasa dikenal jabon merah adalah pohon dengan tajuk seperti payung besar sehingga jika ditanam dengan jarak berapapun tidak akan mempengaruhi bentuk batang (Halawane et al. 2011). Samama juga mampu menggugurkan ranting dan daun bagian bawah secara alami sehingga dapat tumbuh lurus tanpa cabang (Mulyana et al. 2011). Penelitian ini akan menggunakan 3 jenis rumput yang memiliki daya tumbuh baik di bawah naungan terdiri atas: Stenotaphrum secundatum, Paspalum notatum, Pennisetum purpureum Cv. Mott. Ketiga jenis rumput tersebut diketahui memiliki toleransi yang baik terhadap naungan.

Tujuan dari penelitian ini adalah untuk menganalisis pengaruh kerapatan pohon samama dan pengaruh pemupukan nitrogen terhadap pertumbuhan dan 
produktivitas rumput serta menentukan jenis rumput terbaik yang memiliki toleransi terhadap naungan.

\section{METODE PENELITIAN}

Penelitian dilaksanakan di lokasi silvopastura hasil kerjasama KUNAK KPS Bogor, SEAMEO BIOTROP, dan PT Toyota Motor Manufacturing Indonesia (PT TMMIN). Analisis kesuburan tanah dilakukan di laboratorium tanah SEAMEO BIOTROP. Pelaksanaan penelitian dilakukan pada bulan Maret sampai Juli 2015.

Alat yang digunakan adalah cangkul, kantong plastik, penggaris, timbangan, Luxmeter, spiracle densiometer, pita ukur, tambang, phiband, pancang, label, parang, oven, bor biopori, gunting, spidol, tali rafia, alat tulis, dan karung.

Bahan yang digunakan terdiri atas: stek rumput $S$. secundatum, $P$. notatum dan $P$. purpureum Cv.Mott yang diperoleh dari hasil budidaya Laboratorium Lapang Agrostologi, Fakultas Peternakan Institut Pertanian Bogor. Pupuk urea, KCL, TSP, dan pupuk kandang.

Tahap awal penelitian yaitu melakukan orientasi lapang untuk mendapatkan areal yang akan dijadikan demplot penelitian sesuai dengan jumlah kerapatan pohon yang ditentukan. Selanjutnya dilakukan pengukuran tinggi, diameter, dan tutupan tajuk samama. Informasi terkait sifat kimia tanah seperti $\mathrm{pH}$ tanah, kandungan bahan organik, nitrogen, serta unsur-unsur hara yang lain diamati dengan pengambilan sampel tanah menggunakan metode tanah terusik (Hardjowigeno 2010). Sebelum pengolahan tanah terlebih dahulu dilakukan pembersihan lahan (land clearing).

Penempatan plot percobaan dalam demplot dilakukan secara acak dan disesuaikan dengan kondisi lahan. Total luas demplot penelitian adalah $768 \mathrm{~m}^{2}$ terdiri dari 12 petak berukuran $8 \times 8 \mathrm{~m}^{2}$ dengan model petak terbagi / terpisah. Petak utama terdiri dari jumlah kerapatan pohon $(0,2,4,6$ pohon/petak), didalamnya terdapat anak petak yang terdiri dari dosis pemupukan nitrogen $\left(0,100\right.$, dan $\left.200 \mathrm{~kg} \mathrm{~N} \mathrm{ha}^{-1}\right)$ yang disusun vertikal membentuk blok, sementara anak-anak petak terdiri dari jenis rumput $(S$. secundatum, $P$. notatum dan $P$. purpureum $\mathrm{Cv}$. Mott) yang disusun secara acak dengan 9 kali ulangan.

Penanaman ketiga jenis rumput dilakukan secara terpisah sehingga dalam satu petak terdapat ketiga jenis tanaman dengan posisi teracak. Jarak tanam antara rumput yang satu dengan yang lainnya sebesar 50 x 50 $\mathrm{cm}$. Tanah yang sudah digemburkan diberikan pupuk dasar yang terdiri dari pupuk kandang (10 ton $\mathrm{ha}^{-1}$ ) yang disebarkan secara merata pada semua plot percobaan, kemudian lahan dibiarkan selama satu minggu setelah itu dilanjutkan pemberian pupuk TSP $\left(70 \mathrm{~kg} \mathrm{ha}^{-1}\right)$ dan KCL (125 kg ha ${ }^{-1}$ ) untuk melengkapi kebutuhan $\mathrm{P}$ dan K. Stek ditanam dengan posisi miring sekitar $45^{\circ}$ ke arah timur. Tanaman dibiarkan tumbuh 2 minggu setelah tanam untuk dilakukan penyeragaman tinggi tanaman (trimming). Perlakuan pemupukan nitrogen diberikan di sekitar lubang tanam pada awal penanaman. Pupuk dibenamkan dalam tanah dengan membentuk lingkaran pada setiap rumpun rumput dengan dosis.

Parameter yang diamati selama 4 bulan pengamatan yaitu: (1) persentase penutupan tajuk, (2) pengukuran intensitas cahaya, (3) tinggi rumput, (4) jumlah anakan, (5) jumlah anakan sekunder, (6) bobot kering, (7) analisis nitrogen yang hanya dilakukan pada 2 jenis rumput yang memiliki produktivitas tumbuh yang baik.

Rancangan percobaan yang digunakan adalah rancangan acak kelompok (RAK) mengingat banyak faktor dan kondisi tempat penelitian yang tidak dapat dihomogenkan, dengan petak petak terbagi / terpisah (split split plot design). Data tinggi, jumlah anakan primer, jumlah anakan sekunder, bobot kering dan analisis nitrogen dianalisis menggunakan software SAS 9.1. Apabila hasil uji sidik ragam menunjukkan pengaruh yang nyata, maka akan dilakukan uji lanjut Duncan.

\section{HASIL DAN PEMBAHASAN}

\section{Pengaruh naungan terhadap pertumbuhan dan produktivitas rumput}

Perubahan keterikkan cahaya matahari pada suatu permukaan akan menyebabkan perubahan pada unsurunsur iklim lainnya. Cahaya sangat besar peranannya dalam proses fisiologi seperti fotosintesis, respirasi, pertumbuhan dan perkembangan, penutupan dan pembukaan stomata, berbagai pergerakan tanaman dan perkecambahan (Taiz dan Zeiger 2002).

Tabel 1 menunjukkan taraf kerapatan N0 dengan intensitas cahaya penuh, taraf $\mathrm{N} 1$ dengan naungan $34.3 \%$ (intensitas cahaya pagi $70.48 \%$ siang $95.2 \%$ ), taraf $\mathrm{N} 2$ dengan naungan $63.67 \%$ (intensitas cahaya pagi $26.82 \%$ siang $26.71 \%$ ), taraf $\mathrm{N} 3$ dengan naungan $84.3 \%$ (intensitas cahaya pagi $20.01 \%$ siang $15.37 \%$ ).

Tabel 1 Tinggi, diameter, persentase penutupan tajuk samama dan intensitas cahaya pada setiap plot penelitian

\begin{tabular}{cccccccc}
\hline & & & \multicolumn{5}{c}{ intensitas cahaya } \\
\cline { 4 - 7 } S & $\mathrm{D}(\mathrm{cm})$ & $\mathrm{T}(\mathrm{m})$ & $\mathrm{TJ}(\%)$ & $\begin{array}{c}\text { pagi } \\
\text { (lux) }\end{array}$ & PC pagi $(\%)$ & Siang (lux) & PC siang $(\%)$ \\
\hline S0 & & & 0 & 367.3 & 100 & 808.02 & 100 \\
S1 & 4.6 & 4.8 & 34.33 & 258.86 & 70.48 & 769.94 & 95.29 \\
S2 & 4.1 & 5.1 & 63.67 & 98.51 & 26.82 & 215.83 & 26.71 \\
S3 & 5 & 5.5 & 84.33 & 51.8 & 20.01 & 124.2 & 15.37 \\
\hline
\end{tabular}

S0: 0 pohon/plot; S1: 2 pohon/plot; S2: 4 pohon/plot; S3: 6 pohon/plot; S: kerapatan pohon; D: diameter pohon; $\mathrm{T}$ : tinggi pohon; TJ: tutupan tajuk pohon; PC: persentase cahaya 
Pengukuran intensitas cahaya pagi pada pukul 08.0009.00 WIB dan cahaya siang pada pukul 12.00-13.00 WIB. Hasil analisis sidik ragam dari semua peubah yang diamati di lapangan, disajikan dalam Tabel 2.

Berdasarkan hasil analisis keragamanan (Tabel 2), faktor tunggal kerapatan pohon memberikan pengaruh yang nyata $(\mathrm{P}<0.05)$ terhadap peubah jumlah anakan primer. Dari gambar di bawah (Gambar 1) menunjukkan jumlah anakan terbaik pada kerapatan S0 sebanyak 23 anakan/plot, pada kerapatan S1 sebanyak 14 anakan/plot dan pada kerapatan S2 dan S3 sebanyak 6 anakan/plot. Berdasarkan hasil uji lanjut Duncan, JAP pada kerapatan S0 tidak berbeda dengan kerapatan S1, akan tetapi berbeda dengan kerapatan S2 dan S3.

Pertumbuhan jumlah anakan terbaik pada tingkat kerapatan S0 dan S1 dibandingkan tingkat kerapatan lainnya (Gambar 1). Peningkatan kerapatan pohon menurunkan jumlah anakan pada setiap rumput. Hal ini dijelaskan juga dalam penelitian (Mishra et al. 2010) dimana jumlah anakan Cenchrus ciliaris L menurun di bawah naungan pohon Acacia tortilis (Forssk) dibandingkan tanpa naungan. Hal ini terjadi karena pada tanaman di bawah naungan menggunakan energi lebih banyak untuk meningkatkan tinggi tanaman dalam efisiensi penangkapan cahaya (etiolasi) (Mariani dan Jumaedi 2009).

Berdasarkan hasil analisis keragamanan (Tabel 2), faktor tunggal kerapatan pohon memberikan pengaruh yang nyata $(\mathrm{P}<0.05)$ terhadap produksi berat kering. Pada Gambar 2 di bawah ini dapat dilihat produksi berat

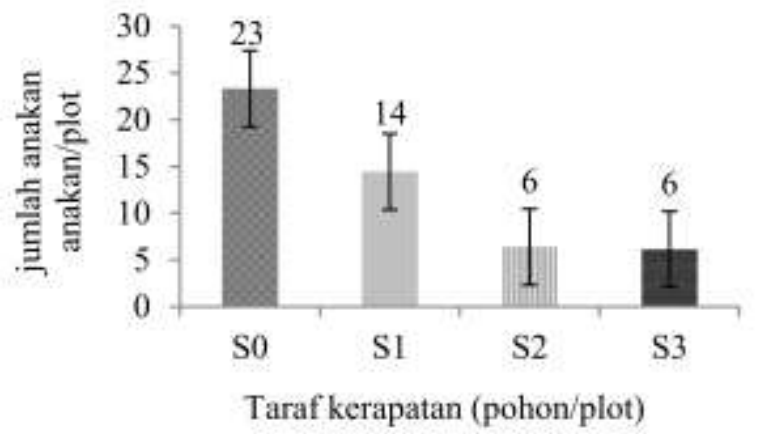

Gambar 1 Jumlah anakan pada setiap jenis rumput S0: 0 pohon/plot, S1: 2 pohon/plot, S2: 4 pohon/plot, S3: 6 pohon/plot kering terbaik pada taraf kerapatan S0 seberat 1.730 gram dibandingkan dengan taraf kerapatan S1 seberat 1.305 gram, taraf kerapatan S2 seberat 840 gram dan kerapatan S3 seberat 694 gram.

Berdasarkan Gambar 2 kerapatan S0 dan S1 memiliki produksi berat kering terbaik sebesar 1730 gram dan 1304 gram. Peningkatan jumlah naungan dari pohon samama berbanding terbalik dengan produksi BK tanaman. Semakin tinggi naungan maka semakin rendah produksi BK tanaman. Naungan yang lebih dari 50\% dari jumlah radiasi dapat mempengaruhi produksi biomassa rumput hijauan tropis (Guenni et al. 2008; Abraham et al. 2014) karena mengurangi rata-rata fotosintesis pada rumput C4 (Santiago et al. 2016). Sirait et al. (2005) menyatakan peningkatan taraf naungan akan menurunkan produksi berat kering. Fotosintesis dan akumulasi bahan kering sangat erat kaitannya dengan PAR (Photosynthetically Active Radiation) yang tersedia untuk keberlanjutan produksi jenis rumput dalam sistem silvopastura untuk periode yang lebih lama (Mishra et al. 2010).

Menurunnya produksi biomassa di bawah naungan, hal ini berhubungan dengan $\mathrm{N}$, memberikan efek yang tidak baik dari kurangnya cahaya yang mengakibatkan pembatasan produksi biomasa. Di bawah cahaya rendah, tanaman tidak bisa merespon $\mathrm{N}$ dengan baik dikarenakan kurangnya cahaya (Paciullo et al. 2016). Hal ini juga terjadi pada penelitian Barnes (2015) menemukan naungan sangat mengurangi akumulasi biomasa Chloris ventricosa (spesies C4 lokal Australia).

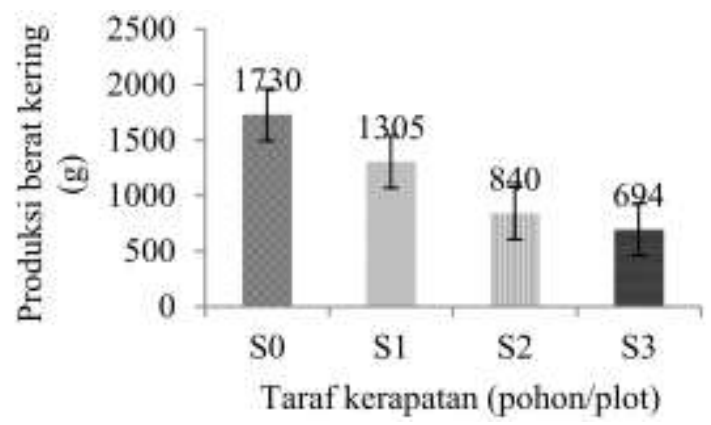

Gambar 2 Produksi berat kering pada setiap taraf kerapatan pohon (g). S0: 0 pohon/ plot; S1: 2 pohon/plot; S2: 4 pohon/plot; S3: 6

Tabel 2 Rekapitulasi hasil analisa sidik ragam terhadap semua parameter

\begin{tabular}{|c|c|c|c|c|c|c|c|}
\hline Parameter & $\mathrm{S}$ & $\mathrm{P}$ & $\mathrm{R}$ & $\mathrm{S} * \mathrm{P}$ & $\mathrm{S} * \mathrm{R}$ & $\mathrm{P} * \mathrm{R}$ & $\mathrm{S} * \mathrm{P} * \mathrm{R}$ \\
\hline Tinggi (T) & tn & tn & $* *$ & $\operatorname{tn}$ & $* *$ & $\operatorname{tn}$ & tn \\
\hline $\begin{array}{l}\text { Jumlah anakan } \\
\text { primer (JAP) }\end{array}$ & $*$ & tn & $* *$ & tn & tn & tn & tn \\
\hline $\begin{array}{l}\text { Jumlah anakan } \\
\text { sekunder (JAS) }\end{array}$ & $* *$ & tn & $* *$ & tn & tn & tn & tn \\
\hline Produksi berat kering (BK) & $*$ & tn & $* *$ & tn & tn & tn & tn \\
\hline Analisis nitrogen R0 & tn & tn & & $\operatorname{tn}$ & & & \\
\hline Analisis nitrogen R2 & $\operatorname{tn}$ & tn & & $\operatorname{tn}$ & & & \\
\hline
\end{tabular}

\footnotetext{
**: berpengaruh sangat nyata pada selang kepercayaan $1 \%$; : berpengaruh nyata pada selang kepercayaan 5\%;
} tn: tidak berpengaruh nyata; S:kerapatan pohon; P:pemupukan; R:jenis rumput; MST: minggu setelah tanam; R0: Stenotaphrum secundatum; R2: Pennisetum purpureum $\mathrm{Cv}$. Mott 


\section{Pemilihan jenis rumput untuk silvopastura di bawah tegakan samama}

Hasil keragaman faktor tunggal jenis rumput terhadap produksi berat kering (Gambar 3) menunjukkan pengaruh yang sangat nyata $(\mathrm{P}<0.01)$. Rumput $P$. purpureum cv. Mott (R2) menghasilkan produksi berat kering terbaik dihasilkan seberat 2339.3 gram dibandingkan dengan rumput $S$. secundatum (R0) dan $P$. notatum (R1) berturut-turut 578.5 gram dan 522.8 gram.

Gambar 4 di bawah ini menunjukkan jumlah anakan sekunder terbaik pada jenis R0 sebanyak 29 stolon/plot

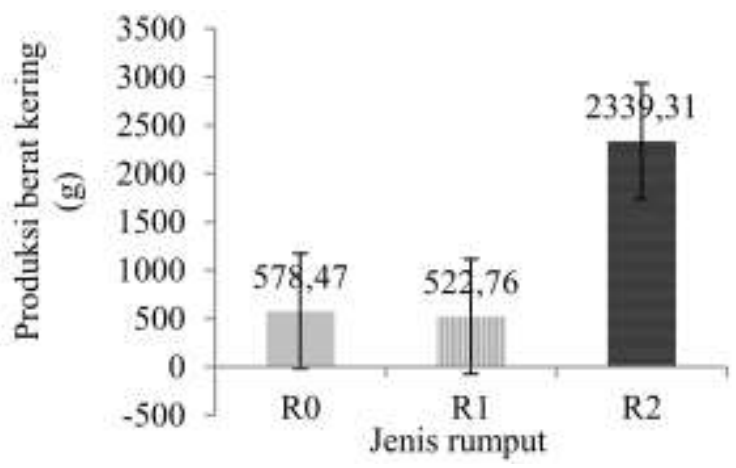

Gambar 3 Berat kering pada setiap jenis rumput R0: Stenotaphrum secundatum, R1: Paspalum notatum, R2: Pennisetum purpureum cv.Mott

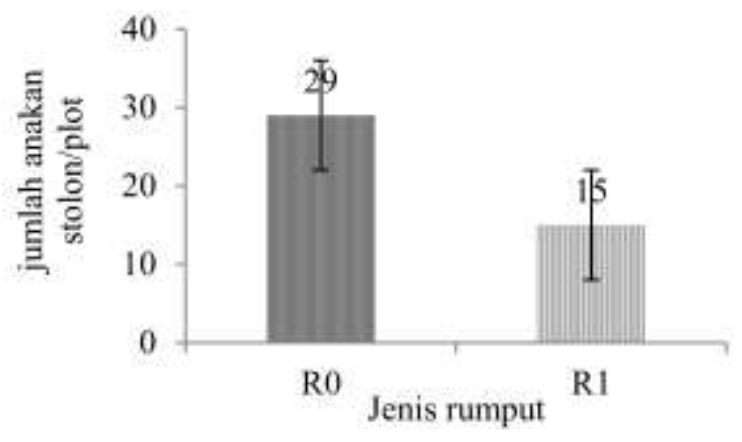

Gambar 4 Jumlah anakan sekunder pada setiap jenis rumput R0: Stenotaphrum secundatum R1: Paspalum notatum, R2: Pennisetum purpureum cv.Mott

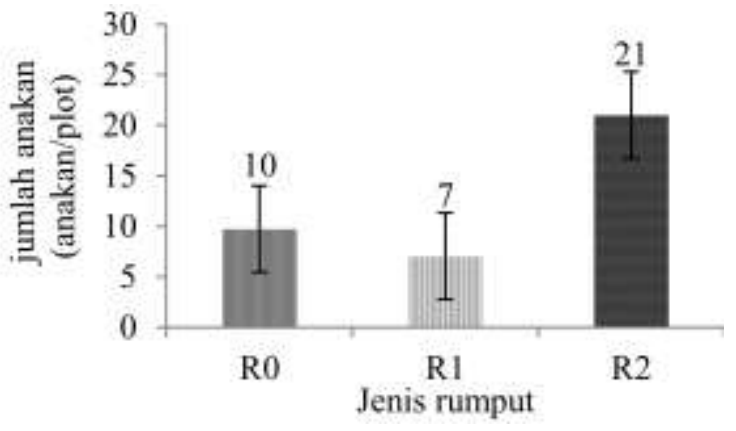

Gambar 5 Jumlah anakan pada jenis rumput R0: Stenotaphrum secundatum, R1: Paspalum notatum, R2: Pennisetum purpureum Cv. Mott dibandingkan dengan jenis R1 sebanyak 15 stolon/plot. Pengukuran jumlah anakan sekunder hanya dilakukan pada jenis rumput benggala, sedangkan pada rumput potong (R2) tidak dilakukan karena tidak memiliki stolon.

Berdasarkan hasil analisis keragamanan (Tabel 2), interaksi tunggal jenis rumput memberikan pengaruh yang sangat nyata $(\mathrm{P}<0.01)$ terhadap peubah jumlah anakan. Jumlah anakan terbaik pada jenis R2 sebanyak 21 anakan/plot dibandingkan dengan jenis R0 sebanyak 10 anakan/plot dan jenis R1 sebanyak 7 anakan/plot pada Gambar 5.

Analisis keragaman faktor tunggal jenis rumput terhadap pertumbahan tinggi menghasilkan pengaruh yang sangat nyata $(\mathrm{P}<0.01)$. Rumput $P$. purpureum $\mathrm{cv}$. Mott menghasilkan tinggi terbaik setinggi $155.34 \mathrm{~cm}$ dibandingkan dengan rumput $S$. secundatum setinggi $113.48 \mathrm{~cm}$ dan rumput $P$. notatum setinggi $37.99 \mathrm{~cm}$ (Gambar 6).

Aspek lain yang perlu dipertimbangkan selain produksi hijauan dan adaptasi sistem ini adalah pertumbuhan rumput tropis sangat dibatasi oleh nitrogen (defisiensi N) (Silveira et al. 2015). Penelitian lain menunjukkan manfaat naungan sedang pada rumput yang tumbuh di tanah nitrogen rendah alami (Wilson 1996). Salah satu penjelasan bahwa kelembaban tanah berkurang lebih lambat di bawah naungan daripada di kondisi matahari penuh, yang dapat menguntungkan bagi aktivitas mikroba di serasah serta proses mineralisasi. Dengan demikian dapat meningkatkan ketersediaan nitrogen di dalam tanah.

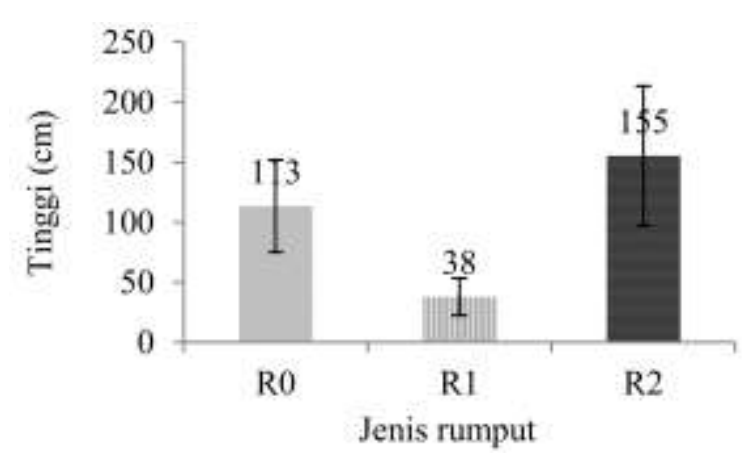

Gambar 6 Pertumbuhan tinggi pada jenis rumput (cm) R0: S. secundatum; R1: P. notatum; R2: P. purpureum Cv. Mott

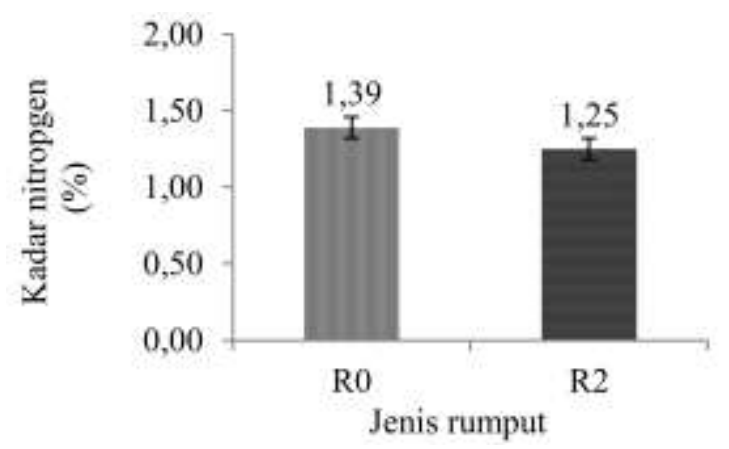

Gambar 7 Kadar nitrogen pada setiap jenis rumput (\%). R0: Stenotaphrum secundatum; R2: Pennisetum purpureum $\mathrm{Cv}$. Mott 
Petumbuhan terbaik selama pengamatan di lapangan untuk jenis yang dipilih adalah jenis R0 dan R2. Dilihat dari Gambar 7 di bawah ini, kadar nitrogen pada jenis R0 sebesar $1.39 \%$ lebih tinggi dibandingkan dengan jenis R2 sebesar $1.25 \%$. Kadar nitrogen yang terdapat pada tanaman tidak sama untuk jaringan yang berbeda. Whitehead (2000) mengemukakan bahwa kebanyakan jaringan tanaman mengandung 1 sampai 5\% kadar nitrogen berdasarkan bahan kering. Kadar nitrogen merupakan salah satu indikator kualitas tanaman pakan (TPT). Semakin tinggi kadar nitrogen suatu TPT akan semakin baik kualitasnya dan pada akhirnya akan memberikan kontribusi positif terhadap ternak yang mengkonsumsinya (Sirait 2006).

Kendala utama dalam kegiatan silvopastura adalah rendahnya intensitas cahaya yang disebabkan faktor naungan dari tajuk pohon samama. Oleh karena itu perlu didapatkan jenis tanaman yang mampu mempertahankan pertumbuhan dan produktivitasnya (toleran) di bawah tegakan pohon samama.Pemilihan jenis rumput yang toleran di bawah tegakan samama dilihat dari pertumbuhan dan produktivitas yang baik di bawah naungan. Dari semua peubah yang diamati, tinggi tanaman, jumlah anakan, dan produksi berat kering, jenis R2 memiliki nilai yang unggul, meskipun kadar nitrogen pada jenis R0 lebih tinggi daripada R2, namun jika dihitung serapan nitrogennya, jenis R2 jauh lebih unggul dari R0 bahkan pada tingkat kerapatan S3.

Berdasarkan uraian diatas, dapat disimpulkan jenis R2 adalah jenis yang paling toleran untuk dikombinasikan dalam sistem silvopastura di bawah tegakan samama dengan tingkat kerapatan S1 dengan tidak melepas ternak langsung ke padang penggembalaan (extensive), penanaman rumput jenis R2 dalam pola silvopastur secara ekstensif kurang efektif. Hal ini dikarenakan jenis R2 merupakan rumput potong yang tidak tahan terhadap pengembalaan berat, untuk itu perlu dikombinasikan dengan jenis R0 yang merupakan jenis rumput gembala yang memiliki rhizoma dan stolon yang padat, memiliki perakaran yang kuat dan mampu berkompetisi dengan gulma dan tahan terhadap penggembalaan berat walaupun produktifitasnya lebih rendah bila dibandingkan dengan R2. Pengembangan silvopastura dengan pengandangan ternak secara intensive dapat dilakukan dengan suplai makanan dari jenis rumput $\mathrm{R} 2$.

\section{SIMPULAN}

Kerapatan 2 pohon/plot (312 pohon/ha) dengan intensitas cahaya pada pagi hari sebesar $70.48 \%$ dan 95.29\% pada siang hari adalah yang paling baik dalam pola silvopastur. Pemupukan nitrogen tidak diperlukan pada tanah dengan kandungan bahan organik yang tinggi dan terdapat pengandangan ternak di dalamnya. Pennisetum purpureum Cv. Mott memiliki toleransi yang paling baik di bawah tegakan samama sebagai sumber rumput potong (pengandangan secara intensif) dan Stenotaphrum secundatum sebagai rumput benggala dalam pengelolaan silvopastur secara ekstensif.

\section{DAFTAR PUSTAKA}

Abraham EM, Kyriazopoulos AP, Parissi ZM, Kostopoulou P, Karatassiou M, Anjalanidou K, Katsouta C. 2014. Growth, dry matter production, phenotypic plasticity and nutritive value of three natural populations of Dactylis glomerata L. under various shading treatments. Agroforestry Systems. 88: 287-299.

Barnes P, Wilson BR, Reid N, Bayerlein L, Koen TB, Olupot G. 2015. Examining the impact of shade on above-ground biomass and normalized difference vegetation index of $\mathrm{C} 3$ and $\mathrm{C} 4$ grass species in North-Western NSW, Australia. Grass and Forage Science. 70:324-334.

Guenni O, Seiter S, Figueroa R. 2008. Growth responses of three Brachiaria species to light intensity and nitrogen supply. Tropical Grassland. 42:75-87.

Halawane JE, Hidayah HN, Kinho J. 2011. Prospek pengembangan samama (Anthocephalus macrophyllus (Roxb.) Havil), solusi kebutuhan kayu masa depan. Manado (ID): Badan Penelitian dan Pengembangan Kehutanan Manado.

[KemenLHK] Departemen Kehutanan. 2015. Peraturan Menteri Lingkungan Hidup dan Kehutanan Republik Indonesia Nomor: P.12 Tahun 2015 tentang Pembangunan Hutan Tanaman Industri. Jakarta (ID): Kemenhut.

[KemenLHK] Departemen Kehutanan. 2015. Peraturan Menteri Lingkungan Hidup dan Kehutanan Republik Indonesia Nomor: P.14 Tahun 2015 tentang Tata Cara Pemberian Izin Usaha Pemanfaatan Kawasan Silvopastura pada Hutan Produksi. Jakarta (ID): Kemenhut.

Lasamadi RD, Malalantang SS, Rustandi, Anis SD. 2013. Pertumbuhan dan perkembangan rumput gajah Dwarf (Pennisetum puprpureum cv. Mott) yang diberi pupuk organik hasil fermentasi $\mathrm{EM}_{4}$. Jurnal Zootek. 32(5):156-162.

Lawrie RA. 2003. Ilmu Daging. Universitas Indonesia. Jakarta.

Mariani SM, Jumaedi A. 2009. Pengaruh intensitas naungan dan kombinasi pemupukan $\mathrm{N}$ dan $\mathrm{P}$ terhadap pertumbuhan, produksi simplisia serta kandungan androgpholida pada sambiloto (Andrographis paniculata). Makalah Seminar Departemen Agronomi dan Hortikultura. Bogor. Institut Pertanian Bogor.

Mishra AK, Tiwari HS, Bhatt RK. 2010. Growth, biomass production and photosynthesis of Cenchrus ciliaris L. under Acacia tortilis (Forssk). Hayne based silvopastoral systems in semi arid tropics. Environmental Biology. 31(6):989-991.

Mulyana D, Asmarahman, Fahmi I. 2011. Mengenal kayu samama dan jabon putih; panduan lengkap bisnis dan bertanam kayu jabon. Jakarta (ID); Agromedia Pustaka.

Paciullo DSC, Gomide CAM, Castro CRT, Mauriciot RM, Fernandes PB, Morenz MJF. 2016. Morphogenesis, biomass and nutritive value Pannicum maximum under different shade levels 
and fertilizer nitrogen rates. Grass and Forage Science. DOI: 10.1111/gfs.12264(1-11).

[RI] Republik Indonesia. 1999. Undang-undang RI Nomor: 41Tahun 1999 tentang Kehutanan. Jakarta (ID): Republik Indonesia.

Santiago HF, Lopez OS, Avila RC, Jarillo RJ, Perez HP, Guerrero RJD. 2016. Physiological and production responses of four grasses from the genera Urochloa and Megathyrsus to shade from Melia azedarch L. Agroforestry Systems. 90: 339-349.

Sarwono H. 2010. Ilmu Tanah. CV Akademika Pressindo. Jakarta.

Silveira ML, Vendramini JMB, Sellers B, Mmonteiro FA, Arthur AG, Ddupas E. 2015. Bahia grass response and $\mathrm{N}$ loss from selected $\mathrm{N}$ fertilizer sources. Grass and forage science. 70:154-160.
Sirait J. Purwantari ND, Simanihuruk K. 2005. Produksi dan serapan nitrogen rumput pada naungan dan pemupukan yang berbeda. JITV. 10(3):177-180.

Sirait J. 2006. Dinamika nitrogen dan produksi rumput benggala (Panicum maximum $\mathrm{Cv}$ Riversdale) pada tiga taraf naungan dan pemupukan. Jakarta, Indonesia. Jakarta (ID); Pusat penelitian dan pengembangan peternakan. 958-966.

Taiz L, Zeiger E. 2002. Plant Physiology $3^{\text {rd }}$ Edition. Sinauer Associates. Sunderland.

Wilson JR. 1996. Shade-stimulated growth and nitrogen uptake by pasture grasses in a subtropical environment. Australian Journal of Agriculture Research. 47:179-189. 